\title{
ULTRASOUND-GUIDED SUPRACLAVICULAR BRACHIAL PLEXUS BLOCK WITH OR WITHOUT DEXMEDETOMIDINE AS AN ADJUVANT TO 0.5\% LEVOBUPIVACAINE- A COMPARATIVE STUDY
}

\author{
Gurulingappa A. Patil1, Sateesh G. C2, Priyanka Pattanshetty ${ }^{3}$
}

${ }^{1}$ Associate Professor, Department of Anaesthesiology, Mahadevappa Rampure Medical College, Kalaburagi, Karnataka, India. ${ }^{2}$ Postgraduate Student, Department of Anaesthesiology, Mahadevappa Rampure Medical College, Kalaburagi, Karnataka, India. ${ }^{3}$ Postgraduate Student, Department of Anaesthesiology, Mahadevappa Rampure Medical College, Kalaburagi, Karnataka, India.

\section{ABSTRACT}

\section{BACKGROUND}

Peripheral nerve block as an anaesthetic technique plays an important role in modern regional anaesthesia compared with general anaesthesia which includes excellent pain control, shortened stay in post anaesthetic care unit and reduced side effects..$^{1,2}$ Upper limb surgeries are mostly performed under brachial plexus block. In this prospective, randomised, double-blind comparative study, we evaluated the effectiveness of the addition of dexmedetomidine to $0.5 \%$ levobupivacaine in ultrasound-guided supraclavicular brachial plexus block for upper limb orthopaedic surgeries.

\section{MATERIALS AND METHODS}

After obtaining Institutional Ethical Committee approval, a double-blind, randomised, prospective, comparative study was conducted on 60 American Society of Anaesthesiologist Grade I and II patients in the age group of 18 - 55 years. Sample size of total 60 patients were randomly allocated into one of the two groups of 30 patients each. Group A received $30 \mathrm{~mL} 0.5 \%$ levobupivacaine with $1 \mathrm{~mL}$ isotonic sodium chloride and Group B received solution containing $30 \mathrm{~mL}$ of $0.5 \%$ levobupivacaine with $1 \mathrm{~mL}$ dexmedetomidine ( $1 \mu \mathrm{g} / \mathrm{kg}$ body weight) for ultrasound-guided supraclavicular brachial plexus block. The effects were studied in terms of onset and duration of sensory and motor blockade, duration of analgesia, haemodynamic changes and complications if any.

\section{RESULTS}

The time of onset of sensory blockade was $6.6 \pm 0.72$ mins in Group A and $5.83 \pm 0.69$ mins in Group B, while the onset time of motor blockade was $8.1 \pm 0.73$ mins in Group A and $7.2 \pm 0.61$ mins in Group B. The duration of sensory blockade was $358.3 \pm$ 42.42 mins in Group A and $455 \pm 39.45$ mins in Group B, while the duration of motor blockade was $271.66 \pm 29.48$ mins in Group A and $307 \pm 35.83$ mins in Group B and the duration of analgesia was $322 \pm 31.44$ mins in Group A and $372 \pm 24.41$ mins in Group B.

\section{CONCLUSION}

Addition of $1 \mu \mathrm{g} / \mathrm{kg}$ dexmedetomidine to $0.5 \%$ levobupivacaine for supraclavicular brachial plexus block shortens sensory and motor block onset time, extends sensory block, motor block and analgesia durations.

\section{KEYWORDS}

Ultrasound-Guided Supraclavicular Brachial Plexus Block, Dexmedetomidine, Levobupivacaine.

HOW TO CITE THIS ARTICLE: Patil GA, Sateesh GC, Pattanshetty P. Ultrasound-guided supraclavicular brachial plexus block with or without dexmedetomidine as an adjuvant to 0.5\% levobupivacaine- a comparative study. J. Evolution Med. Dent. Sci. 2017;6(43): 3376-3379, DOI: $10.14260 / \mathrm{Jemds} / 2017 / 731$

\section{BACKGROUND}

Peripheral nerve block as an anaesthetic technique plays an important role in modern regional anaesthesia compared with general anaesthesia, which includes excellent pain control and shortened stay in post-anaesthetic care unit and reduced side effects.1,2 Upper limb surgeries below the shoulder joint are mostly performed under peripheral blocks, such as the brachial plexus block. The conventional landmark technique for supraclavicular brachial plexus block being a blind technique may be associated with higher failure rate and injury to nerves and vascular structures.

Financial or Other, Competing Interest: None.

Submission 08-04-2017, Peer Review 16-05-2017,

Acceptance 22-05-2017, Published 29-05-2017.

Corresponding Author:

Dr. Sateesh G. C,

Postgraduate Student,

Department of Anaesthesiology,

Mahadevappa Rampure Medical College,

Kalaburagi, Karnataka, India.

E-mail: gcsateesh@gmail.com

DOI: $10.14260 /$ jemds $/ 2017 / 731$

\section{(c) $($ ) $\ominus$}

To overcome these the ultrasound technique ${ }^{3}$ is employed; the advantage being avoidance of intraneuronal/intravascular injection, visualisation of spread of local anaesthetic, low volume of drug, faster onset of action and decreased need for rescue analgesia.

In our current prospective, randomised, double-blind study we evaluated the effectiveness of the addition of 1 $\mu \mathrm{g} / \mathrm{kg}$ dexmedetomidine to $0.5 \%$ levobupivacaine for supraclavicular brachial plexus block in terms of:

1. Onset and duration of sensory and motor blockade.

2. Duration of analgesia.

3. Haemodynamic changes.

4. Complications if any.

Levobupivacaine (S (-)-enantiomer of bupivacaine) with favourable clinical profile and lesser cardiotoxicity when compared with racemic bupivacaine ${ }^{4,5}$ is being favoured LA for regional block.

Dexmedetomidine, a selective $\alpha 2$-adrenoceptor agonist has analgesic, sedative, antihypertensive and anaesthetic sparing effects when used in systemic ${ }^{6}$ route. 
Dexmedetomidine has also shown to prolong the duration of the block and post-operative analgesia when added to local anaesthetic in various regional blocks. ${ }^{7}$

\section{MATERIALS AND METHODS}

After approval from Institutional Ethical Committee, consents were taken from patient and their relatives. 60 patients of ASA I and II of either sex, who were scheduled to undergo upper limb (i.e. elbow, forearm and hand) orthopaedic surgery under supraclavicular brachial plexus block were included in the study sample size of total 60 patients satisfying inclusion criteria are randomly allocated into one of the two groups of 30 patients each. Randomisation was done by a computer-generated table of random numbers. In Group 1 patients received $30 \mathrm{~mL}$ of levobupivacaine, $0.5 \%$ with $1 \mathrm{~mL}$ of normal saline, while in Group 2 patients received injection dexmedetomidine $1 \mathrm{~mL}$ (dose- $1 \mu \mathrm{g} / \mathrm{kg}$ body weight) in addition to $30 \mathrm{~mL}$ of levobupivacaine $0.5 \%$. The study drug was prepared by an anaesthesiologist not involved in the study and the anaesthesiologist performing the block was blinded about the study drug.

\section{Exclusion Criteria}

1. Patient's refusal.

2. Patients with history of bleeding disorders.

3. Patients with local infection at the site of block.

4. Patients with pre-existing peripheral neuropathy.

5. Patients with hepatic or renal disease.

6. Patients with hypertension and heart blocks.

7. Patients with known allergy to local anaesthetic drugs.

Patients had undergone routine pre-anaesthetic evaluation a day before surgery. All patients fasted for $8 \mathrm{hrs}$. before surgery. In the operation theatre, all patients were monitored with ECG, pulse oximeter, non-invasive blood pressure monitor. An intravenous line was secured with 18-G cannula on non-operative limb and infusion of lactated ringer started. Supplemental oxygen was provided to all the patients through nasal cannula throughout the surgery.

Patients will be pre-medicated with Inj. Ondansetron 0.1 $\mathrm{mg} / \mathrm{kg}$ and Inj. Midazolam $0.05 \mathrm{mg} / \mathrm{kg}$ intravenously. Baseline measurement of Heart Rate (HR), non-invasive blood pressure and SpO2 were recorded before the block was performed. With all aseptic precautions, ultrasound-guided supraclavicular brachial plexus block was given with the patient lying supine with the head turned to opposite side using a 23-G, $55 \mathrm{~mm}$ needle.

Assessment of sensory blockade was done in the dermatomal areas corresponding to median nerve, radial nerve, ulnar nerve and musculocutaneous nerve. Sensory blockade was tested using pin prick method along the distribution of the four nerves. Sensory block ${ }^{8}$ is graded as Grade $0=$ Sharp pain felt, Grade 1= Analgesia, dull sensation felt, Grade 2= Anaesthesia, no sensation felt.

Sensory onset was considered when there is no sensation to pin prick (Grade 2) along the distribution of any of the above-mentioned nerves. The duration of sensory block was considered as the time interval from complete sensory block till first postoperative pain.

Motor blockade assessment was done using the modified Bromage ${ }^{9}$ scale for upper extremities on a three-point scale.
Grade $0=$ normal motor function with full flexion and extension at elbow, wrist and fingers, Grade 1= decreased motor strength with ability to move fingers only, Grade 2= complete motor blockade with inability to move fingers.

Onset of motor blockade was considered when there is Grade 2 motor blockade. The duration of motor block is defined as the time interval between the onset of motor block and recovery of complete motor function of the hand and forearm.

Sensory and motor blocks were evaluated every minute for first 15 mins, every 3 mins for next 15 mins, within first 30 mins following completion of drug administration, if there is incomplete blockage it is considered as failed block. Vital parameters (pulse rate, blood pressures and Sp02) were recorded every 5 mins for first 30 mins and thereafter every 10 mins till the end of surgery.

Postoperatively, motor and sensory blockade and vital parameters of the patient were noted half hourly till the block completely wears off and hourly for 24 hours. Pain is assessed using $10 \mathrm{~cm}$ Visual Analog Scale (VAS) scores. If VAS score is 3 or more, rescue analgesic Inj. diclofenac $75 \mathrm{mg}$ IM given.

Adverse events such as hypotension (20\% decrease in relation to the baseline value), bradycardia (HR $<60 \mathrm{bpm}$ ), hypoxaemia (SpO2 90\%) and perioperative nausea and vomiting were recorded.

Onset and total duration of sensory and motor blockade, haemodynamic stability, sedation and any other adverse effect will be noted.

\section{Statistical Analysis}

Data was analysed using SPSS 16.0 version software. Student's unpaired t-test and Fisher's Exact test were applied for statistical data analysis and $\mathrm{P}<0.05$ is considered statistically significant.

\section{RESULTS}

A total of 60 patients were enrolled in this study. The demographic characteristics were similar in each group and were statistically insignificant $(\mathrm{P}>0.05)$ [Table 1].

\begin{tabular}{|c|c|c|c|}
\hline $\begin{array}{c}\text { Demo- } \\
\text { graphic } \\
\text { Data }\end{array}$ & $\begin{array}{c}\text { Group-A } \\
\text { (n= 30) } \\
\text { (M } \pm \text { SD) }\end{array}$ & $\begin{array}{c}\text { Group-B } \\
\text { (n= 30) } \\
\text { (M } \pm \text { SD) }\end{array}$ & P value \\
\hline Age (years) & $36.86 \pm 9.23$ & $35.43 \pm 8.84$ & $\begin{array}{c}0.54 \text { (Student's } \\
\text { unpaired t-test) }\end{array}$ \\
\hline $\begin{array}{c}\text { Weight (kg) } \\
\text { Sex Ratio } \\
\text { (male: } \\
\text { female) }\end{array}$ & $59.33 \pm 7.86$ & $57.96 \pm 8.81$ & $\begin{array}{c}0.52 \text { (Student's } \\
\text { unpaired t-test) }\end{array}$ \\
\hline $\begin{array}{c}\text { Duration of } \\
\text { Surgery } \\
\text { (min) }\end{array}$ & $115.33 \pm 16.76$ & $114.66 \pm 16.33$ & $\begin{array}{c}0.37 \text { (Fisher's } \\
\text { Exact Test) } \\
\text { unpaired t-test) }\end{array}$ \\
\hline \multicolumn{4}{|c|}{ Table 1 } \\
\hline
\end{tabular}

The time of onset of sensory blockade was $6.6 \pm 0.72$ mins in Group A and $5.83 \pm 0.69$ mins in Group B, while the onset time of motor blockade was $8.1 \pm 0.73$ mins in Group A and $7.2 \pm 0.61$ mins in Group B. The duration of sensory blockade 
was $358.3 \pm 42.42$ mins in Group A and $455 \pm 39.45$ mins in Group B, while the duration of motor blockade was $271.66 \pm$ 29.48 mins in Group A and $307 \pm 35.83$ mins in Group B and the duration of analgesia was $322 \pm 31.44$ mins in Group A and $372 \pm 24.41$ mins in Group B (Table 2).

\begin{tabular}{|c|c|c|c|}
\hline $\begin{array}{c}\text { Block } \\
\text { Characteristics }\end{array}$ & $\begin{array}{c}\text { Group-A } \\
(n=30) \\
(M \pm S D)\end{array}$ & $\begin{array}{c}\text { Group-B } \\
(n=30) \\
(M \pm S D)\end{array}$ & $P$ value \\
\hline $\begin{array}{l}\text { Onset of Sensory } \\
\text { Blockade (min) }\end{array}$ & $6.6 \pm 0.72$ & $5.83 \pm 0.69$ & $\begin{array}{c}<0.001 \\
\text { (Student's } \\
\text { unpaired } \\
\mathrm{t} \text {-test) }\end{array}$ \\
\hline $\begin{array}{l}\text { Onset of Motor } \\
\text { Blockade (min) }\end{array}$ & $8.1 \pm 0.73$ & $7.2 \pm 0.61$ & $\begin{array}{c}<0.001 \\
\text { (Student's } \\
\text { unpaired } \\
\text { t-test) }\end{array}$ \\
\hline $\begin{array}{c}\text { Duration of Sensory } \\
\text { Blockade (min) }\end{array}$ & $358.3 \pm 42.42$ & $455 \pm 39.45$ & $\begin{array}{c}<0.001 \\
\text { (Student's } \\
\text { unpaired } \\
\text { t-test) }\end{array}$ \\
\hline $\begin{array}{c}\text { Duration of Motor } \\
\text { Blockade (min) }\end{array}$ & $271.66 \pm 29.48$ & $307 \pm 35.83$ & $\begin{array}{c}<0.001 \\
\text { (Student's } \\
\text { unpaired } \\
\text { t-test) }\end{array}$ \\
\hline $\begin{array}{c}\text { Duration of } \\
\text { Analgesia (min) }\end{array}$ & $322 \pm 31.44$ & $372 \pm 24.41$ & $\begin{array}{c}<0.001 \\
\text { (Student's } \\
\text { unpaired } \\
\text { t-test) }\end{array}$ \\
\hline \multicolumn{4}{|c|}{ Table 2} \\
\hline
\end{tabular}

We observed a statistically significant difference $(\mathrm{P}<0.05)$ in HR between two groups from 10 mins after the block, which extended in the postoperative period up to 12 hrs.

A statistically significant difference was observed in SBP and DBP from 10 mins that extended into the postoperative period.

Bradycardia (HR $<60$ ) was observed in 3 patients in Group B, but none of them required treatment. Both the groups were comparable for $\mathrm{RR}$ and $\mathrm{SpO} 2$ at each interval and the results were statistically insignificant. None of the patients in either group had technique or drug-related side effects or complications.

\section{DISCUSSION}

Upper limb orthopaedic surgeries are known to cause severe postoperative pain. Supraclavicular brachial plexus block is given with local anaesthetic agents for upper limb surgeries and is not only an anaesthetic method, but also allows easier postoperative pain control.

In the present randomised, double-blind study, we demonstrated that the addition of dexmedetomidine to $0.5 \%$ levobupivacaine in supraclavicular brachial plexus block results in faster onset of sensory and motor blockade as well as prolonged duration of sensory and motor blockade, prolong the duration of postoperative analgesia and provides significantly lower postoperative VAS pain scores.

Local anaesthetic agent selection, dose, concentration, volume and physical modifications can affect onset, spread, quality and duration of anaesthesia. Levobupivacaine, the Senantiomer of bupivacaine which has less cardiac and neural toxicity than bupivacaine, $, 4,5$ is currently the closest to the ideal agent for neural blockade.

Dexmedetomidine, the pharmacologically active D-isomer of medetomidine is a highly specific and selective $\alpha 2$ adrenoceptor agonist with $\alpha 2$ : $\alpha 1$ binding selectivity ratio of 1620: 1 , thus decreasing the unwanted side effects of $\alpha 1$ receptors. ${ }^{10}$

At clinically effective doses, high selectivity for $\alpha 2 \mathrm{~A}$ receptors mediates analgesia, sedation, anxiolysis and lacks respiratory depression.6,11 The research done so far shows encouraging results for its use in intravenous sedation (ICU and operative patients), spinal,12 epidural,13 caudal anaesthesia $^{14}$ and Bier's block. ${ }^{15}$ By its effects on spinal $\alpha 2$ receptors, it prolongs analgesia when used with local anaesthetics for neuraxial blocks. ${ }^{16}$

No animal study has shown any evidence of neurotoxicity when administering dexmedetomidine (even at high concentrations) directly to sciatic nerves. ${ }^{17}$ Peripheral analgesic effects of dexmedetomidine have enabled an overall improved blockade quality when added to LAs in a peripheral nerve block model and are thought to be mediated by $\alpha 2 \mathrm{~A}$ binding. ${ }^{18}$

In a randomised, double-blind trial performed by Esmaoglu et al $^{19}$ dexmedetomidine added to levobupivacaine for axillary brachial plexus blockade shortened the block onset time, prolonged the duration of motor and sensory effects and extended postoperative analgesia.

Swami et al used dexmedetomidine and clonidine as an adjuvant to bupivacaine $0.25 \%$ in supraclavicular plexus block and demonstrated that dexmedetomidine prolongs the duration of sensory and motor block and enhances the quality of block as compared with clonidine.

Major limitations of our study were that we could not biochemically analyse the blood concentration of levobupivacaine and dexmedetomidine due to unavailability of facilities at our institution. Further randomised trials need to be conducted to validate the findings of our study.

\section{Limitation}

Major limitations of our study were, sample size was not estimated scientifically and we could not biochemically analyse the blood concentration of levobupivacaine and dexmedetomidine due to unavailability of facilities at our institution. Further randomised trials need to be conducted to validate the findings of our study.

\section{CONCLUSION}

The results of our study conclude that the addition of $1 \mu \mathrm{g} / \mathrm{kg}$ dexmedetomidine to $0.5 \%$ levobupivacaine for supraclavicular plexus block decreases onset time for sensory and motor block, prolongs the duration of sensory and motor block and duration of analgesia. Thus, making dexmedetomidine an attractive choice as an adjuvant to levobupivacaine for supraclavicular brachial plexus block.

\section{REFERENCES}

[1] Liu SS, Strodtbeck WM, Richman JM, et al. A comparison of regional versus general anesthesia for ambulatory anesthesia: a meta-analysis of randomized controlled trials. Anesth Analg 2005;101(6):1634-42. 
[2] McCartney CJ, Brull R, Chan VW, et al. Early but no long-term benefit of regional compared with general anesthesia for ambulatory hand surgery. Anesthesiology 2004;101(2):461-7.

[3] McCartney CJ, Lin L, Shastri U. Evidence basis for the use of ultrasound for upper-extremity blocks. Reg Anesth Pain Med 2010;35(2 Suppl):S10-5.

[4] Foster RH, Markham A. Levobupivacaine: a review of its pharmacology and use as a local anaesthetic. Drugs 2000;59(3):551-79.

[5] Mazoit JX, Boïco O, Samii K. Myocardial uptake of bupivacaine: II. Pharmacokinetics and pharmacodynamics of bupivacaine enantiomers in the isolated perfused rabbit heart. Anesth Analg 1993;77(3):477-82.

[6] Hall JE, Uhrich TD, Barney JA, et al. Sedative, amnestic, and analgesic properties of small-dose dexmedetomidine infusions. Anesth Analg 2000;90(3):699-705.

[7] Swami SS, Keniya VM, Ladi SD, et al. Comparison of dexmedetomidine and clonidine (2 agonist drugs) as an adjuvant to local anaesthesia in supraclavicular brachial plexus block: a randomised double-blind prospective study. Indian J Anaesth 2012;56(3):243-9.

[8] Crews JC, Weller RS, Moss J, et al. Levobupivacaine for axillary brachial plexus block: a pharmacokinetic and clinical comparison in patients with normal renal function or renal disease. Anesth Analg 2002;95(1):219-23.

[9] Sarkar DJ, Khurana G, Chaudhary A, et al. A comparative study on the effects of adding fentanyl and buprenorphine to local anaesthetics in brachial plexus block. Journal of Clinical and Diagnostic Research 2010;4(6):3337-43.

[10] Carollo DS, Nossaman BD, Ramadhyani U. Dexmedetomidine: a review of clinical applications. Curr Opin Anaesthesiol 2008;21(4):457-61.
[11] Belleville JP, Ward DS, Bloor BC, et al. Effects of intravenous dexmedetomidine in humans. I. Sedation, ventilation, and metabolic rate. Anesthesiology 1992;77(6):1125-33.

[12] Kanazi GE, Aouad MT, Jabbour-Khoury SI, et al. Effect of low-dose dexmedetomidine or clonidine on the characteristics of bupivacaine spinal block. Acta Anesthesiol Scand 2006;50(2):222-7.

[13] Konakci S, Adanir T, Yilmaz G, et al. The efficacy and neurotoxicity of dexmedetomidine administered via the epidural route. Eur J Anaesthesiol 2008;25(5): 403-9.

[14] El-Hennawy AM, Abd-Elwahab AM, Abd-Elmaksoud $\mathrm{AM}$, et al. Addition of clonidine or dexmedetomidine to bupivacaine prolongs caudal analgesia in children. $\mathrm{Br} \mathrm{J}$ Anaesth 2009;103(2):268-74.

[15] Abosedira MA. Adding clonidine or dexmedetomidine to lignocaine during biers block: a comparative study. J Med Sci 2008;8:660-4.

[16] Ishii H, Kohno T, Yamakura T, et al. Action of dexmedetomidine on the substantia gelatinosa neurons of the rat spinal cord. Eur J Neurosci 2008;27(12):3182-90.

[17] Brummett CM, Norat MA, Palmisano JM, et al. Perineural administration of dexmedetomidine in combination with bupivacaine enhances sensory and motor blockade in sciatic nerve block without inducing neurotoxicity in rat. Anesthesiology 2008;109(3):502-11.

[18] Yoshitomi T, Kohjitani A, Maeda S, et al. Dexmedetomidine enhances the local anesthetic action of lidocaine via an alpha-2A adrenoceptor. Anesth Analg 2008;107(1):96-101.

[19] Esmaoglu A, Yegenoglu F, Akin A, et al. Dexmedetomidine added to levobupivacaine prolongs axillary brachial plexus block. Anesth Analg 2010;111(6):1548-51. 